\title{
7 Driving factors in the adoption of Industry 4.0 technologies
}

\author{
An investigation of SMEs
}

Giancarlo Corò and Mario Volpe

\subsection{Introduction}

The growing diffusion of a new generation of digital technologies is leading to innovations in communication, production and work to such an extent that several scholars agree that it amounts to new industrial revolution (Bianchi and Labory 2018; Brynjolfsson and McAfee 2014; McQuivey 2013; Schwab 2016). This digital revolution, or Industry 4.0 (I4.0), is expected to increase flexibility, reduce lead times, allow mass customization, enable new services based on big data and create appealing work structures (Heng 2014). Productivity gains might be substantial, opening up opportunities in every industry. At the same time, such changes present a number of challenges, the most significant being increasing job substitution and social inequality (Cowen 2013; Frey and Osbourne 2017).

Given the framework presented in Chapter 1, the aim of this chapter is to provide some empirical evidence of the enabling factors that can assist firms' adoption of specific technologies related to I4.0. Drawing on Frey and Osbourne's (2017) argument on the impact of computerization on jobs, our core objective is to explore the relationship between the adoption of I4.0 technologies and either job creation or destruction. Moreover, we are interested in analysing the synergies between the use of digital technologies and firms' internationalization and financial structure.

There are three main contributions that this chapter makes to the current debate. The first is to provide empirical evidence on the degree of adoption of specific I4.0 technologies by different types of firms, using primary data collected via a survey. Despite the amount of attention that I4.0 has received in the media and in the policy debate, little robust evidence is available on the diffusion of such technologies. The second contribution of is to profile what types of firms are more likely to adopt specific technologies; we find that such firms are more likely to employ high-skill workers, have better links with international markets and have good financial leverage. In other words, there are some enabling factors that facilitate firms' adoption of I4.0 technologies. Moreover, it has emerged that firms tend to adopt combinations of such technologies rather than a single one, which is consistent with the theoretical 
framework of I4.0 (Platform I4.0 2015). Finally, our evidence shows that firms adopting advanced digital technologies also tend to increase their employment in the short term.

Drawing on Arthur (2009), technology is defined here as an assemblage of practices and components, collections or toolboxes to reach human goals. From this perspective, we consider I4.0 as a cluster of technologies characterized by high levels of connectivity that allow data and information integration in the production and consumption activities. More specifically, we consider I4.0 as including the following seven technologies: robotics, the industrial Internet of Things (IoT), smart products, additive manufacturing (3D printing), big data, augmented reality and the virtualization of IT systems (cloud computing). For the purposes of this work, the expressions 'digital technologies' and 'I4.0 technologies' are interchangeable, since they both refer to the above-listed technologies in line with, among others, the EU definition as spelt out in the I4.0 and digital agendas (EU Parliament 2015a, 2015b) following the German policy that introduced the term Industrie 4.0 for the first time (Kagermann et al. 2013).

The chapter will proceed as follows. Section 7.2 will discuss the economic literature on the potential of digital innovation and technologies for businesses. Section 7.3 will discuss the uptake of the I4.0 model in Italy. Section 7.4 will present the data collection and outline the methodology employed in the analysis. Sections 7.5 and 7.6 will describe the main findings of the survey and will discuss the relationship between adoption of digital technologies and three different enabling factors: internationalization, financial structure and human capital. Section 7.7 will summarize with a few concluding remarks.

\subsection{Digital innovation and technological upgrading}

The world of digital technologies is commonly linked to what is now called 'Industry 4.0' (Baur and Wee 2015). This, in turn, is usually associated with the emergence of cyber-physical systems - i.e. highly automated and hyperconnected production processes - that are expected to redraw the organization of production inside the factory (Broy 2013), as well as involving the reorganization of supply chains (Platform I4.0 2015) and a reconceptualization of both products and processes (Schmidt et al. 2015). Therefore, the new industrial paradigm is expected to manifest itself in a multi-faceted way with transformations that are widespread and disruptive.

This idea of I4.0 is linked to similar paradigms that have been often referred to as 'Advanced Manufacturing', 'Integrated Industry', 'Smart Industry' or 'Smart Manufacturing' (Hermann et al. 2015). These latter concepts are similar, but tend to emphasize distinct aspects; therefore, there is no consensus on one definition of I4.0 (Hermann et al. 2015; Liao et al. 2017). The difficulty in defining the phenomenon is partly due to the different perceptions that companies and stakeholders hold regarding digitization and I4.0. Sommer (2015) has shown that the importance of change is widely recognized, even 
though very few companies are ready to invest, or are already investing, in that direction.

In the current debate, I4.0 is often assumed to be linked to the Fourth Industrial Revolution (Schwab 2016), following the previous three that are widely accepted in the literature and are associated, respectively, with steam power, electricity and computerization (Rullani 1989). Other authors, by contrast, consider today's digital innovation still as the tail end of the Third Industrial Revolution that started in the 1970s with the introduction of computers in business processes (Gordon 2016). According to Thames and Schaefer (2016), the main goals of I4.0 are to achieve a higher level of productivity and efficiency, as well as a higher level of automation. These will allow mass customization of products, fast adaptation of production chains, innovative value chain organizations, and new types of services and business models (Shafiq et al. 2015, 2016). The economic potential of this transformation could be huge (Rüßmann et al. 2015), but its evaluation is very difficult because of the vast number of technologies involved and of the different maturity levels for each of the technologies (Schröder 2016; Hermann 2015; Hofmann and Rüsch 2017). For a more detailed literature review and discussion of I4.0, see Liao et al. (2017), Lu (2017) and Kang et al. (2016).

Although the aim of this chapter is not to elaborate on whether I4.0 is associated either with a revolutionary industrial paradigm shift (Schwab 2016) or with an evolutionary process of digitalization that started in the 1970s (Gordon 2016), it is worth highlighting a couple of points that will help frame the following empirical analysis. Firstly, there are some elements of originality in the current phase of digitalization that distinguish 'Industry 4.0' from the computerization of the 1970s and 1980s, such as the combination of different technologies into cyber-physical systems and cloud-based manufacturing (Thames and Schaefer 2016). In particular, we recall some elements of the literature on digitalization and ICT technologies that can also apply to I4.0, but that have not yet been explicitly investigated by the I4.0 literature. The existing literature on ICT has mainly highlighted the difficulties in estimating the value generated by digital technologies (Grover and Kohli 2012; Yoo et al. 2012) and, consequently, in assessing the impact of the ongoing transformation. Due to the ever-increasing technological integration, the 'digital' side is difficult to evaluate separately from the 'non-digital' side.

Secondly, another problem is represented by the lack of shared criteria to identify what makes a business 'digital' or part of the I4.0 paradigm. Thus, the implementation and adoption of digital technologies by firms surely depend on the IT infrastructure. Although these are essential for further development, it may be misleading to consider this digital upgrading only as a part of an evolved ICT system (OECD 2014). Previous studies have also emphasized that digitalization and IT promote access to innovative ideas (Pisano and Verganti 2008), mainly sustaining the knowledge flow (Katz and Rice 2002) and changing how individuals interact (Hinds and Kiesler 2002). Therefore, openness and the creation of networks are essential in order for firms to compete. Firms will improve 
the relationship between individuals and business practices with internet-based technologies (Vaccaro and Madsen 2009), thus enabling digital technologies to create new types of innovation processes (Henfridsson et al. 2014).

Thirdly, firms need to design and implement an appropriate joint IT and business strategy depending on their competitive context, creating a digital organization and IT capabilities in order ultimately to be able to create value from digital innovation (Fichman 2012). Mere investments in IT infrastructure and related technologies are not enough, even though a well-designed IT architecture is essential to develop new products and processes (Fink 2007). Evidence shows that social and organizational capital both have a positive relationship with the adoption of innovations (Dost et al. 2016).

Fourthly, the ability to collect and manage multiple types of information is crucial for the innovation and exploitation of digital technologies (OECD 2015). Managing big data (Lycett 2013) is the key to creating value, employing information that is usually already available and whose potential only needs recognition in order to be released (Fosso Wamba et al. 2015). No evidence of a widespread awareness of the importance of data is available, as academics have in fact put forward very few models to evaluate the maturity level of data management (Comuzzi and Patel 2016). Thus, the main barriers to create value from data management and analytics are mainly managerial and cultural at the firm level rather than related to the technology itself (La Valle et al. 2011). Overcoming such barriers could lead to an improvement in firms' intellectual and human capital (Secundo et al. 2017), which might benefit both businesses and individuals. Furthermore, the impact of data management is not limited to already existing business models; it can also enable the creation of brand new data-driven business models (Hartmann et al. 2016).

Further, evidence shows that investments that do not involve human capital are less likely to lead to productivity gains, especially in small firms (Díaz-Chao et al.2015). In fact, a positive relationship between product, service and process innovations and 'innovative human capital' has also been observed (McGuirk et al.2015). Although there is no consensus that improving human and intellectual capital will enhance innovation in the broader sense (Buenechea-Elberdin 2017), it seems essential to accomplish digital transformation. For instance, Cirillo (2016) shows that hi-tech industries, influenced by international contexts, usually show greater productivity, accompanied by employment growth associated with high-skilled talent. Conversely, low-tech industries require lower-skilled workers, command lower wages and rely on more flexible labour. At present, learning by doing and intra-firm training are both essential. Evidence from Evangelista et al. (2014) indicates that in order to leverage the adoption of digital technologies, life-long learning seems to be more important than formal education.

Finally, openness to international markets has a positive impact on innovation activities in both large and small enterprises (Boermans and Roelfsema 2016). Access to international markets allows firms to benefit from economies of scale to pay back the fixed costs of innovation, and enables entrepreneurs, 
technicians and managers to be part of wider knowledge networks. A positive link exists not only between internationalization and innovation, but also between these two factors and productivity (Altomonte et al. 2013). Moreover, several empirical studies confirm a positive correlation between the use of digital technologies and export activities (Morgan-Thomas and Jones 2009; Higón and Driffield 2011; Bianchi et al. 2016; Cassetta et al. 2016). However, almost all of them consider the front-end applications of digitalization, using variables such as the use of ICT, social media and e-commerce. Conversely, the digitalization of productive processes has so far been under-studied.

\subsection{Industry 4.0 in Italy}

I4.0 has become a highly debated topic in Italy only in the last couple of years. For a long time, the discussion concerned a superficial interpretation of the German model, often focusing on a few single technologies. Recently, the attention has been shifting towards a more holistic and realistic vision.

From recent studies (Federmeccanica 2016; Fondazione Nord-Est 2015), it has emerged that the adoption processes of some technologies seem to be already in place. Indeed, views collected from entrepreneurs and managers seem to suggest that some technologies - such as additive printing, 3D scanning and advanced cutting systems - are basically an evolution of technologies already in use, greatly reducing the costs involved in the adoption of their later generations. On the other hand, the adoption of the IoT and virtual reality is, for instance, still limited and distant from many businesses' daily activities. This can be explained by the radical change of technological paradigm under way and thus of the consequent new business models that many of these technological solutions involve (e.g. in relation to the most extreme forms of servitization). In such a delicate transition, Italian firms tend to rely too little on the knowledge and expertise they could access from universities and research centres.

It is clear that the debate on the Fourth Industrial Revolution has so far been strongly linked to technological aspects, mostly driven by the narrow German model that has led the way. This technological primacy has contributed to creating a climate of mistrust and concern amongst businesses, especially amongst small and medium-sized firms which cannot fully understand the potentials that such technologies present to them. These doubts also arose from the way in which I4.0 was presented to companies with a strong emphasis placed on the adoption of, for instance, robotics, sensoring and relatively high-cost technologies, which small businesses have struggled to recognize as relevant for them, given the business model that has characterized their competitive advantage for years. Therefore, it is crucial to shift the debate on I4.0 from the mere technological aspects to a more systemic vision that has been captured in this volume using the term Industry $4.0+$.

The Italian government launched a national plan to support the upgrading of firms' machinery stocks in 2016: the 'Piano Industria 4.0'. This provided financial support to firms of any size and industry to buy new machinery and 
equipment. Superficially, this seems to be endorsing an understanding of I4.0 as purely associated with the technological content of firms' capital stocks; however, the small size of the majority of Italian firms had prevented them in the recent past from undertaking the necessary investments to keep up with advances in technology. Besides, Italy has a very competitive and export-oriented mechanical engineering sector that nevertheless benefited from a boost in domestic demand. Therefore, the government plan must be understood as acting on two levels: firstly, to raise awareness of what I4.0 might mean and imply; and, secondly, to encourage firms to inject some technological upgrading in their production. The initial plan expected a private commitment of over $€ 56$ billion for the period 2017-2020, in view of a public commitment of around $€ 24$ billion.

\subsection{Case study of $\mathbf{I} 4.0$ in Veneto}

To analyse the diffusion of digital technologies in Veneto, a survey was administered to manufacturing, construction and services companies during the autumn of 2015. The aim of the survey was to investigate the awareness and diffusion among firms of the following technologies: automation and robotics, the industrial IoT, smart products, additive manufacturing, mixed reality, big data and the virtualization of IT systems. The survey also included in-depth questions on additive manufacturing. Firm case studies with structured interviews followed the collection of data.

\subsubsection{Data and methodology}

Primary data collection was carried out through an online survey administered in the autumn of 2015 to a stratified sample of firms in the Veneto region; the survey was facilitated by the Chamber of Commerce of Treviso and Belluno. The targeted sample of firms for the survey was selected according to the following criteria: manufacturing firms must have had at least six employees and a minimum of $€ 1$ million production value; construction firms must have had more than 20 employees; and service firms must have had at least three employees and a minimum production value of $€ 250,000$.

Table 7.1 shows the number of respondents, divided by sector. Sectors were identified according to the NACE rev. 2 classification. The sub-division was

Table 7.1 Respondents by sector: absolute numbers and percentages

\begin{tabular}{lcc}
\hline Sector & Respondents & Percentage of total \\
\hline Manufacturing & 633 & 71.04 \\
Construction & 56 & 6.27 \\
Services & 202 & 22.69 \\
Total & 891 & 100 \\
\hline
\end{tabular}

Source: Authors' elaboration. 
operated as follows: manufacturing NACE section C; construction NACE section F; and services NACE sections J and $\mathrm{M}$. The total number of respondents was respectively 633,51 and 207 ; the sample is representative in terms of company size and industry. ${ }^{1}$

Firms were asked if they were familiar with and if they used any of the following digital technologies: robotics and automation, the industrial IoT, smart products, 3D printing, big data, mixed reality (virtual and augmented reality) and virtualization of IT systems. The questionnaire included an accurate definition of each technology in order to clarify and facilitate the comprehension of the task. In the construction and service sectors, 'digital users' were defined as firms adopting at least one of the digital technologies, and in the manufacturing sector, 'digital users' were firms that adopted at least two different technologies. This distinction was necessary in order to shed light on the effects of a combination of different technologies; this appears to be very important for the manufacturing sector.

For all surveyed firms, we were also able to collect administrative data on employment, trade and financial structure from secondary sources for the years 2007-2014. Data on human capital were sourced from 'Veneto Lavoro', the Regional Agency that records all the hiring and cessation movements occurring in the labour market. Data on import and export activities were extracted from the Infocamere and ISTAT databases. Finally, financial data were accessed from the AIDA database (the Italian database available from $\mathrm{BvD})$. These three databases were aligned with the survey database, allowing us to build a unique firm-based dataset with information on the composition of the workforce, the import and export activities, and the financial structure. We analysed this rich database with robust descriptive statistics (Sections 7.5 and 7.6 below).

\subsection{Main findings}

\subsubsection{Awareness and adoption of new digital technologies}

The diffusion of digital technologies in the Veneto region varies across industries. The shares of digital users (as defined above) in the manufacturing and construction sectors are respectively $37 \%$ and $33 \%$, while it is $64 \%$ for services. Therefore, awareness of digital technologies seems to be higher in services and lower in construction. We find the existence of different technological frontiers among sectors. Intensity of use and types of technologies are significantly different depending on firms' activity.

There is also an important gap between levels of awareness and adoption of technologies. Both seem to be the highest in relation to additive manufacturing: $60 \%$ of firms declare that they know of the technology, but less than $10 \%$ use it. The difference in this case - as well as for other technologies - is possibly due to the fact that firms do not use a specific technology in their specific business, but part of the adoption gap can also be explained by a superficial 
knowledge by firms of the possibilities and impact of such digital technologies on their business.

Analysing additive manufacturing in particular, what emerges is that it only used in less than $10 \%$ of firms and it is weakly integrated in business processes. We find that smaller firms have been able to better integrate 3D printing technology in their business and there is no significant impact of the technology on the labour market. Very few jobs were created and in most cases its introduction did not require particular adjustments in terms of labour organization. Furthermore, 3D printing technology is still linked to prototyping, with more than $90 \%$ of firms using it for that purpose. Less than $30 \%$ of respondents declared that they use additive manufacturing for the fabrication of finished or usable products.

Given its sectoral specialization, Italy could greatly benefit from the large number of applications related to the adoption of the latest generations of additive manufacturing technology (Bai et al. 2017). However, the level of adoption in Veneto is still too limited: we find that $51 \%$ of firms are additive-detached, $37 \%$ are additive-integrated and only $12 \%$ can be considered as additiveoriented. Table 7.2 shows our findings in terms of firms' awareness and adoption of digital technologies. It is also worth noting the size of the gap between the firms that declare that they are familiar with some digital technologies and those that actually use them. As expected, we find considerable differences in the diffusion of digital technologies among sectors, with the virtualization of IT systems being the most widely adopted technology, whereas others are more sector-specific.

No relationship between the size of firms and the number of technologies adopted was found. This evidence is consistent with the idea of firms having their own technology frontiers, meaning that each firm selects a specific set of technologies and combines them according to their own specific needs and activities. For example, among the manufacturers of plastic products, it can be noted that $89 \%$ of them use robotics or automation, while none of them declare that they have introduced sensors in 'smart' products.

\subsubsection{Clusters of technologies}

We would argue that the multiple use of technologies can be more significant than the adoption of a single technology for firms. Having found that the size of firms does not play any role in relation to technological adoption, we began to explore whether firms' adoption could depend more on firms' specific technological frontiers or families of technologies they related to because of the sector or activities in which they were specialized. Within this logic, individual technologies were grouped together on the basis of complementarity. Figure 7.1 maps what we found from our survey in terms of technological combinations that firms disclosed. In this network of technologies, the size of the nodes denotes how many times a single technology is used together with another, while the thickness of the links represents how much two technologies 
Table 7.2 Awareness and adoption of digital technologies (\% of total)

\begin{tabular}{|c|c|c|c|c|c|c|c|c|}
\hline \multirow[t]{2}{*}{ Technology } & \multicolumn{2}{|c|}{ Manufacturing } & \multicolumn{2}{|l|}{ Construction } & \multicolumn{2}{|l|}{ Services } & \multicolumn{2}{|l|}{ Total } \\
\hline & Knowledge & Use & Knowledge & Use & Knowledge & Use & Knowledge & Use \\
\hline Robotics & 52.66 & 26.59 & 32.08 & 4.04 & 29.81 & 7.68 & 48.82 & 24.13 \\
\hline Industrial IoT & 37.04 & 13.84 & 21.49 & 9.37 & 33.06 & 9.25 & 38.16 & 15.71 \\
\hline Smart products & 27.35 & 5.23 & 23.05 & 9.37 & 28.86 & 7.78 & 30.98 & 7.63 \\
\hline 3D printing & 58.57 & 8.34 & 44.06 & 1.56 & 52.27 & 6.68 & 58.47 & 13.13 \\
\hline Big data & 25.60 & 9.49 & 28.18 & 12.94 & 36.49 & 20.96 & 34.34 & 17.06 \\
\hline Mixed reality & 32.45 & 6.36 & 30.66 & 4.04 & 37.60 & 16.96 & 38.61 & 11.90 \\
\hline Virtualization of IT systems & 39.93 & 16.87 & 40.32 & 30.22 & 55.56 & 45.21 & 53.65 & 33.67 \\
\hline
\end{tabular}

Source: Authors' elaboration. 


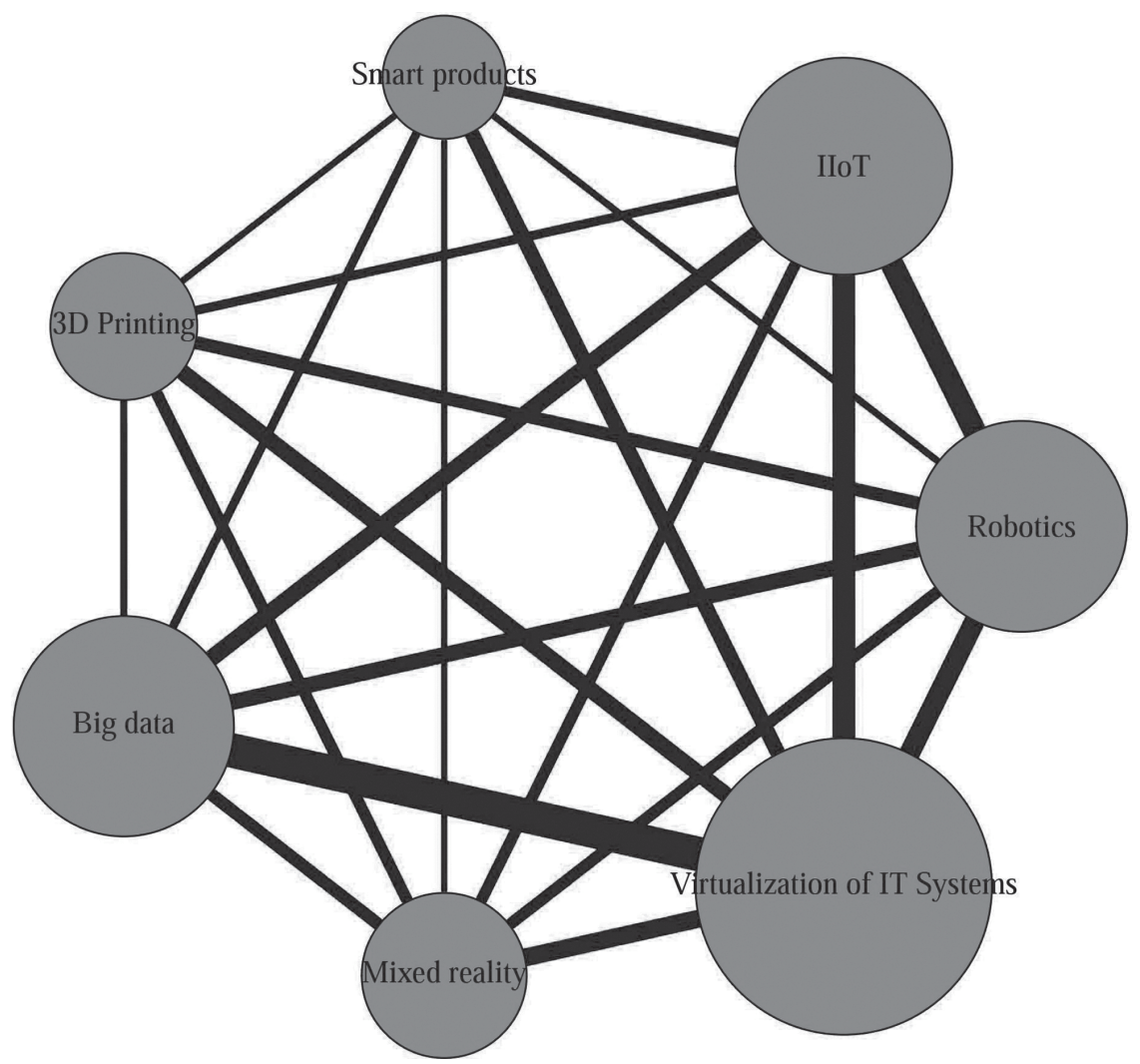

Figure 7.1 Combination of different technologies.

Source: Authors' elaboration.

Notes: The dimension of vertices expresses the number of times a single technology is used together with another. The width of the lines represents the number of times the two technologies are used together.

are used together. Some technologies show a higher level of complementarity than others. Potential clusters of technologies seem to emerge around robotics, the industrial IoT, big data and the virtualization of IT systems. This makes sense since all these technologies are often used together in advanced automation processes. Our evidence is coherent with the theoretical framework of I4.0, where value is created by combining different technologies (Schimtd et al. 2015). Furthermore, the creation of cyber-physical systems, which are the result of the application of I4.0 technologies, necessarily requires the combined adoption of multiple technologies such as robotics, the IoT and big data (Broy 2013; Evangelista et al. 2014). 


\subsection{Enabling factors}

We move on to investigate three other enabling factors impacting on the adoption of digital technologies by firms. These are the quality of human capital in firms, their openness to international markets and their financial structure. We consider each of them in turn.

\subsubsection{Human capital}

Digital users and non-digital users vary in terms of the composition of their workforce. The most significant finding is that digital users employ more highly skilled workers, i.e. people with a degree or high school education (see Table 7.3).This applies to all sectors, even though the difference is more evident in the construction and service sectors. Furthermore, firms using technologies created more jobs in the period 2012-2014 (see Table 7.4). Specifically, the highest growth occurred for highly skilled workers and for those with a degree. Another important fact is that whether or not they use digital technologies, most of the surveyed firms no longer hire unskilled workers. This will result in firms having an increasingly large share of highly and medium-skilled people in their labour and contracting out low-skilled functions.

In the period 2012-2014, digital users (accounting for roughly one-third of the total number of firms) exhibited net occupational growth, recruiting more than $75 \%$ of all the jobs created within the sample firms. This is only partially consistent with evidence from other major European countries, where job creation is led by product innovation and an increase in value added (Cirillo 2016). Investments in technology can be interpreted as process innovation and should

Table 7.3 Composition of the workforce in 2014 (\% of total employment)

\begin{tabular}{|c|c|c|c|c|c|c|c|c|}
\hline & \multicolumn{2}{|c|}{ Manufacturing } & \multicolumn{2}{|c|}{ Construction } & \multicolumn{2}{|l|}{ Services } & \multicolumn{2}{|l|}{ Total } \\
\hline & $\begin{array}{l}\text { Digital } \\
\text { users }\end{array}$ & $\begin{array}{l}\text { Digital } \\
\text { non- } \\
\text { users }\end{array}$ & $\begin{array}{l}\text { Digital } \\
\text { users }\end{array}$ & $\begin{array}{l}\text { Digital } \\
\text { non- } \\
\text { users }\end{array}$ & $\begin{array}{l}\text { Digital } \\
\text { users }\end{array}$ & $\begin{array}{l}\text { Digital } \\
\text { non- } \\
\text { users }\end{array}$ & $\begin{array}{l}\text { Digital } \\
\text { users }\end{array}$ & $\begin{array}{l}\text { Digital } \\
\text { non- } \\
\text { users }\end{array}$ \\
\hline No skills & 12.31 & 10.91 & 10.64 & 16.65 & 0.49 & 3.88 & 10.90 & 10.80 \\
\hline Low skills & 46.18 & 50.81 & 36.17 & 55.81 & 2.55 & 10.60 & 40.75 & 48.25 \\
\hline Medium skills & 16.65 & 16.93 & 21.28 & 13.53 & 34.71 & 54.96 & 18.93 & 19.44 \\
\hline High skills & 24.85 & 21.35 & 31.91 & 14.01 & 62.26 & 30.56 & 29.42 & 21.51 \\
\hline $\begin{array}{l}\text { No academic } \\
\text { qualifications }\end{array}$ & 1.87 & 2.79 & 2.98 & 5.24 & 0.45 & 1.61 & 1.77 & 2.87 \\
\hline $\begin{array}{l}\text { Compulsory } \\
\text { schooling }\end{array}$ & 38.41 & 46.54 & 36.14 & 59.81 & 4.57 & 14.13 & 34.33 & 45.03 \\
\hline High school & 45.02 & 42.61 & 45.47 & 30.78 & 56.92 & 49.69 & 46.43 & 42.33 \\
\hline Degree & 14.70 & 8.05 & 15.41 & 4.17 & 38.06 & 34.57 & 17.47 & 9.77 \\
\hline
\end{tabular}

Source: Authors' elaboration. 
Table 7.4 Employment growth 2012-2014 (\% of total employment growth)

\begin{tabular}{|c|c|c|c|c|c|c|c|c|}
\hline & \multicolumn{2}{|c|}{ Manufacturing } & \multicolumn{2}{|c|}{ Construction } & \multicolumn{2}{|l|}{ Services } & \multicolumn{2}{|l|}{ Total } \\
\hline & $\begin{array}{l}\text { Digital } \\
\text { users }\end{array}$ & $\begin{array}{l}\text { Digital } \\
\text { non- } \\
\text { users }\end{array}$ & $\begin{array}{l}\text { Digital } \\
\text { users }\end{array}$ & $\begin{array}{l}\text { Digital } \\
\text { non- } \\
\text { users }\end{array}$ & $\begin{array}{l}\text { Digital } \\
\text { users }\end{array}$ & $\begin{array}{l}\text { Digital } \\
\text { non- } \\
\text { users }\end{array}$ & $\begin{array}{l}\text { Digital } \\
\text { users }\end{array}$ & $\begin{array}{l}\text { Digital } \\
\text { non- } \\
\text { users }\end{array}$ \\
\hline No skills & -1.24 & -5.16 & -9.52 & 21.93 & -20.00 & 9.68 & -1.88 & -2.52 \\
\hline Low skills & 6.67 & 1.43 & 0.31 & 6.15 & 13.51 & 10.71 & 6.35 & 1.93 \\
\hline Medium skills & 6.76 & 3.75 & -2.56 & 1.80 & 2.88 & 4.10 & 5.27 & 3.73 \\
\hline High skills & 12.48 & 5.73 & 11.76 & 1.74 & 2.81 & -2.19 & 10.01 & 4.68 \\
\hline $\begin{array}{l}\text { Without } \\
\text { academic } \\
\text { qualifications }\end{array}$ & -5.53 & 5.31 & -14.81 & 160.00 & 40.00 & -7.14 & -5.62 & 13.14 \\
\hline $\begin{array}{l}\text { Compulsory } \\
\text { schooling }\end{array}$ & -0.40 & -4.15 & -0.71 & 4.95 & -5.33 & -6.56 & -0.50 & -3.44 \\
\hline High school & 12.18 & 8.14 & 1.15 & 0.88 & 3.76 & 5.53 & 10.22 & 7.51 \\
\hline Degree & 23.28 & 12.58 & 19.00 & 29.17 & 1.72 & 4.49 & 16.78 & 10.73 \\
\hline
\end{tabular}

Source: Authors' elaboration.

thereby have a negative impact on employment; however, our findings suggest that process innovation can be associated with employment growth, driven by productivity growth and new skills requirements. The data in Table 7.4 have to be interpreted in the light of the severe economic crisis that plagued the Veneto production base. Our findings suggest that access to high-skill labour was able to compensate for the negative business environment of the manufacturing and construction sectors in the mid-2010s; however, this was not the case for services, probably because the latter focused too narrowly on the local market (see Table 7.5).

\subsubsection{Firms' internationalization}

Firms' openness to international markets is one of the factors that enable and accelerate the adoption and diffusion of digital technologies. Our findings on the relationship between firms' import/export activities and firms' adoption of digital technologies are reported in Tables 7.5 and 7.6.

In the present analysis, we find that digital users are more open to international markets. The openness to international markets plays a significant role, but only if digital users are strictly defined (i.e. at least three technologies are used). Such a relationship can be seen from two different perspectives. Firstly, digital technologies can represent both a requirement for and a consequence of internationalization. Competing in international markets is likely to be more challenging than doing so in local markets, forcing firms to invest in digital technologies in order for them to reach productivity levels comparable to those of their international competitors. Thus, digital users have effectively higher 
Table 7.5 Share of respondents that have export activities, divided by digital use ( $\%$ of total)

\begin{tabular}{llllll}
\hline & \multicolumn{2}{l}{ Digital users } & & \multicolumn{2}{l}{ Digital non-users } \\
\cline { 2 - 3 } & Export & Do not export & & Export & Do not export \\
\hline Construction & 30.35 & 69.65 & & 8.66 & 91.34 \\
Manufacturing & 73.69 & 26.31 & & 58.27 & 41.73 \\
Services & 8.98 & 91.02 & & 3.70 & 96.3 \\
\hline
\end{tabular}

Source: Authors' elaboration.

Table 7.6 Share of respondents that have import activities, divided by digital use (\% of total)

\begin{tabular}{lccccc}
\hline & \multicolumn{2}{l}{ Digital users } & & \multicolumn{2}{l}{ Digital non-users } \\
\cline { 2 - 3 } \cline { 5 - 6 } & Import & Do not import & & Import & Do not import \\
\hline Construction & 48.51 & 51.49 & & 10.59 & 89.41 \\
Manufacturing & 57.95 & 42.05 & & 47.39 & 52.61 \\
Services & 5.83 & 94.17 & & 8.30 & 91.70 \\
\hline
\end{tabular}

Source: Authors' elaboration.

productivity performances than digital non-users. Secondly, engaging in import and export suggests that such internationally exposed firms operate in global value chains; for them, digital adoption might be necessary in order to collaborate with foreign partners in the supply chains.

\subsubsection{Financial structure and economic performance}

We finally looked at the financial position of firms in order to shed light on the relationship between the adoption of digital technologies and firms' economic performance, as well as looking at firms' access to capital. Specifically, the present investigation focused on the profitability (return on sales (ROS), return on equity (ROE) and return on investment (ROI)), productivity (value added per employee) and capital composition (Leverage, Net Financial Position and Debt/Equity) of firms (see Table 7.7 for details).

Digital users generally show a better financial composition (see Table 7.7). No great differences are evident on the leverage ratios, all being well below the limit of $3 \%$. Additionally, the net financial position (NFP) is considerably higher for firms adopting digital technologies than for firms not adopting digital technologies.

Finally, considering profitability ratios, higher returns can be observed for firms that employ digital technologies in the construction and service sectors. Conversely, for manufacturing firms, the findings are less clear. In particular, 
Table 7.7 Average financial ratios, separating the firms that adopt digital technologies from those that do not

\begin{tabular}{|c|c|c|c|c|c|c|}
\hline & \multicolumn{2}{|c|}{ Manufacturing } & \multicolumn{2}{|c|}{ Construction } & \multicolumn{2}{|l|}{ Services } \\
\hline & $\begin{array}{l}\text { Digital } \\
\text { users }\end{array}$ & $\begin{array}{l}\text { Digital } \\
\text { non-users }\end{array}$ & $\begin{array}{l}\text { Digital } \\
\text { users }\end{array}$ & $\begin{array}{l}\text { Digital } \\
\text { non-users }\end{array}$ & $\begin{array}{l}\text { Digital } \\
\text { users }\end{array}$ & $\begin{array}{l}\text { Digital } \\
\text { non-users }\end{array}$ \\
\hline ROS & 6.17 & 4.78 & 5.67 & 1.90 & 5.75 & 1.79 \\
\hline ROE & 13.65 & 14.73 & 19.61 & 8.12 & 23.71 & 6.92 \\
\hline ROI & 15.47 & 15.70 & 6.36 & 1.35 & 32.04 & 3.86 \\
\hline $\begin{array}{l}\text { Value added per } \\
\text { employee }\end{array}$ & 65.27 & 56.45 & 73.89 & 49.98 & 60.62 & 65.08 \\
\hline Leverage $(\mathrm{L})$ & 1.28 & 1.52 & 2.34 & 1.29 & 1.17 & 2.07 \\
\hline $\begin{array}{l}\text { Net financial } \\
\text { position (NFP) }\end{array}$ & 4.413 & 669 & 11.467 & 1.919 & 121 & 973 \\
\hline Debt/equity & 1.03 & 0.82 & 0.70 & 1.80 & 0.47 & 1.37 \\
\hline
\end{tabular}

Source: Authors' elaboration.

Note:The value added per employee and the net financial position are reported in thousands of $€$. ROS, ROE, ROI and Leverage are percentages.

digital users show a higher return on sales ratio, while ROE and ROI are higher for digital non-users. Nevertheless, the differences are not particularly significant. Additionally, the value added per employee ratio is higher for digital users in the manufacturing and construction sectors; however, in the service sector, digital users show a lower productivity ratio, suggesting that for them, the adoption of digital technologies does not translate into significant improvements in productivity.

However, we found the low profitability ratios for digital users in the manufacturing sector puzzling and we tried to understand the reasons for this. Our analysis finds that firms are adopting the first wave of I4.0 technologies, but have problems that are often related to learning processes. Moreover, innovative firms seems to have higher capital intensity and greater equity and risk capital in their financial position. This kind of capital allows firms to overcome asymmetric information constraining access to credit access and allows them to have more time to benefit from the initial investment.

Secondly, we find that human capital is most important in firms' value added; we looked at the ratio labour cost $(\mathrm{wL})$ over value added (VA) and compared it with high capital intensity. We find that as firms employ more highly skilled employees, their wage bill increases and so does the wL/VA ratio. In other words, firms' lower business profitability in the short term is explained by investment in greater skills and to a lesser extent in fixed capital. Table 7.8 below shows human capital does not account for a greater share of value-added digital users across all sectors. Therefore, the explanation for the low profitability of manufacturing digital users might lie in the reinvestment of the created value and the longer-run ROI. The adoption of digital technologies requires a series of risk investments, such that the higher value created 
Table 7.8 Distribution of the value added between human and risk capital

\begin{tabular}{|c|c|c|c|c|c|c|}
\hline & \multicolumn{2}{|c|}{ Manufacturing } & \multicolumn{2}{|c|}{ Construction } & \multicolumn{2}{|l|}{ Services } \\
\hline & $\begin{array}{l}\text { Digital } \\
\text { users }\end{array}$ & $\begin{array}{l}\text { Digital } \\
\text { non-users }\end{array}$ & $\begin{array}{l}\text { Digital } \\
\text { users }\end{array}$ & $\begin{array}{l}\text { Digital } \\
\text { non-users }\end{array}$ & $\begin{array}{l}\text { Digital } \\
\text { users }\end{array}$ & $\begin{array}{l}\text { Digital } \\
\text { non-users }\end{array}$ \\
\hline $\mathrm{wL} / \mathrm{VA}$ & 0.63 & 0.76 & 0.71 & 0.86 & 0.71 & 0.84 \\
\hline EBITDA/VA & 0.37 & 0.24 & 0.28 & 0.11 & 0.27 & -0.02 \\
\hline EBIT/VA & 0.26 & 0.12 & 0.19 & 0.03 & 0.17 & -0.40 \\
\hline
\end{tabular}

Source: Authors' elaboration

Note: Each indicator is calculated as an average over the last nine years, then considered in logarithmic value.

has to be reinvested in a company's activities instead of being distributed to shareholders. This would keep the ROI and ROE low. Although no data on the levels of investments are available, early indications point in this direction. For instance, the amount of the net fixed assets is four times higher for digital users than for digital non-users ( $€ 16$ million against $€ 4$ million of digital nonusers). This hypothesis needs further testing that is beyond the scope of this chapter (Aboal and Garda 2015).

The same conclusion can be drawn considering the Earnings Before Interest, Taxes, Depreciation and Amortization (EBITDA)/VA ratio (or EBIT/VA, thus mitigating the weight of capital-intense activities). In this case, though, a lower ratio would translate into a higher value added attributed to human capital.

\subsection{Key findings from the empirical evidence}

This chapter introduced the debate about I4.0 in Italy with the launch of the 'Piano Industria 4.0' by the government in 2016. We focused our attention on the diffusion of digital technologies in the Veneto region, as one of the country's most manufacturing-intensive regions. The main findings of the case studies are summarized below.

The first key finding is that firm size does not matter in terms of explaining the rate of adoption of I4.0, especially digital technologies. This confirms a similar result regarding Portuguese firms, also indicating a low correlation between size and the adoption of digital technologies (Faria et al. 2002).

The second key finding is that the adoption of digital technologies seems to cut across sectors. The present analysis shows the existence of different technological frontiers from one sector to another. However, we find that manufacturing firms are less likely to adopt technologies than those in the construction sector, and firms in the service sector show a more significant process of adoption. This finding can be explained by the nature of the manufacturing sector in Veneto, where small and medium-sized enterprises (SMEs) operate mainly in industries that have a competitive advantage in terms of design and 
innovation rather than in terms of price, the so-called 'made-in-Italy' industries such as eyewear, fashion, jewellery and furniture.

Thirdly, we find that firms' international exposure matters: firms' adoption of digital technologies is linked to their engagement in international markets, which is measured by the presence of import and/or export activities. This applies to the manufacturing and construction sectors, but not to services. We find a significant and positive relationship between firms' international exposure and the adoption of digital technologies. This relationship can be explained on two levels, since internationalization is simultaneously a consequence of and a requirement for the adoption of technologies. On the one hand, intense competition in international final markets requires flexibility and productivity levels which can only be achieved through digitalization; on the other hand, the growing need for firms to ingrate into the global supply chain can only be satisfied through ICT-related technologies, forcing them to keep up their technological readiness with global buyers.

Fourthly, another crucial finding is certainly that regarding human capital. The analysis shows that the quality of human capital is significant and positively related to the adoption of technology. We used two proxies for measuring the quality of human capital (the percentage of graduates among all employees and the percentage of highly skilled workers) and they both reinforce the argument that human capital is essential for the adoption of technologies. Analysis of the composition of skills suggests that digital users are characterized by more highly skilled and highly educated workers than digital non-users. Evidence from this study also shows that the digital users are mainly hiring skilled and educated workers. In the period 2012-2014, digital users from the present sample recorded net occupational growth: one-third of the firms accounted for $75 \%$ of all new jobs.

Finally, three different indicators were used to analyse the financial position of firms: the net financial position, the EBITDA and the debt/equity ratio. Of the three alternatives, the more significant indicator appears to be the EBITDA. Therefore, the ability of the firm to create significant and steady earnings seems to positively relate to the adoption of digital technologies. Lower ROI and ROE for digital users suggests that investments in new technologies will deliver over the longer term. Overall, digital users record a better productivity index than digital non-users. The empirical evidence suggests that internal resources represent a strong driver towards the adoption of technological innovation, as is the case in Guarascio and Pianta (2016).

\subsection{Some policy considerations}

Factors enabling an efficient use of digital technologies have to be identified to redirect companies and public investments. The present study and several others underline the value of intangible assets. Specifically, a specialized workforce, quality relations with suppliers, company know-how, wise management and accurate organization all allow the profitable exploitation of digital technologies. Hence, the adoption of a single technology might in itself be necessary, but 
far from sufficient. Therefore, our empirical analysis suggests the crucial role of human capital, which emerges as a key factor in the adoption of digital technologies. Consequently, public policies stimulating investments in the adoption of specific technologies (often embodied in machinery or equipment), like the Italian government's 'Piano Industria 4.0', should couple the technological aspect with the human capital aspect. In our view, the incentives in technology adoption should request a mandatory presence of adequate workers in the firm. Alternatively, the investments in new machinery should be combined with the hiring of new workers and/or with specific learning processes.

To capture all the potential value that digital transformation can add, it is necessary for a company to broaden its horizons and look beyond technological considerations. Hence, a supporting ecosystem that can promote and facilitate the adoption of technologies is essential to enable companies to keep up with their competitors. In doing so, any ideological position on technical revolutions and new industrial paradigms should be disregarded. Each company should choose its own model on the basis of its traditions and needs. Therefore, imposing the same business model on all companies is certainly not feasible and would surely deplete the efforts made and the potential benefits deriving from the implementation of the model. We have seen that digital technologies are not linked to a particular economic sector, but are used across all of them, although with different diffusion rates. This means that policies targeting firms as end-users of digital technologies should not be sector-specific, but should promote a diversity of firms and products, thus boosting territorial resources.

The complex 'job versus technology' issue should also be examined. Clearly, the labour market needs to adapt and adjust. However, concerns about robots replacing human workers are often likely to be speculative and not based on reality. Although the data presented in this work are limited and call for further analysis, our findings suggest that human capital is one of the most crucial elements for the digital transformation. Specifically, fieldwork conducted for this project clearly shows that a technological upgrade is generally accompanied by employment growth, especially in SMEs. This is very important in fragmented systems where no big players dominate the market, as is the case in Italy and most of Europe. Therefore, understanding the true situation is crucial for the realization of benefits and in order to avoid negative effects, whether we are observing a revolution or not.

\subsection{Disclosure statement}

No potential conflict of interest was reported by the authors.

\section{Note}

1 The composition of the sample was statistically tested. The chi-squared test (Pearson 1900; Plackett 1983) confirms that the composition of the universe and the sample correspond, both in terms of dimension and in terms of activities. 


\section{References}

Aboal, D. and Garda, P. 2015. 'Technological and non-technological innovation and productivity in services vis-à-vis manufacturing sectors'. Economics of Innovation and New Technology, 25(5), 435-454.DOI: https://doi.org/10.1080/10438599.2015.1073478.

Altomonte, C., Aquilante, T., Békés, G. and Ottaviano, G.I. 2013. 'Internationalization and innovation of firms: evidence and policy'. Economic Policy, 28(76), 663-700.

Arthur, W.B. 2009. The Nature of Technology: What it is and How it Evolves. Simon \& Schuster, New York.

Baur, C. and Wee, D. 2015. 'Manufacturing's next act'. McKinsey Quarterly, June.

Bai, X., Liu, Y., Wang, G. and Wen, C. (2017). 'The pattern of technological accumulation: the comparative advantage and relative impact of 3D printing technology', Journal of Manufacturing Technology Management, 28(1), 39-55.

Bianchi, C.C., Glavas, C. and Mathews, S.W. 2016. 'SME international performance in Latin America: the role of entrepreneurial and technological capabilities', BALAS 2016 Annual Conference, Guayaquil, Ecuador, available at: https://eprints.qut.edu.au/91536.

Bianchi, P. and Labory, S. 2018. Industrial Policy for the Manufacturing Revolution: Perspectives on Digital Globalisation. Edward Elgar, Cheltenham.

Boermans, M.A. and Roelfsema, H. 2016. 'Small firm internationalization, innovation, and growth'. International Economics and Economic Policy, 13(2), 283-296. DOI: https:// doi.org/10.1007/s10368-014-0310-y.

Broy, M. 2013. 'Engineering cyber-physical systems: challenges and foundations'. In: Aiguier, M., Caseau,Y., Krob, D. and Rauzy, A. (eds), Complex Systems Design \& Management. Springer, Berlin, Heidelberg, pp. 1-13.

Brynjolfsson, E. and McAfee, A. 2014. The Second Machine Age: Work, Progress, and Prosperity in a Time of Brilliant Technologies. WW Norton \& Company, New York.

Buenechea-Elberdin, M. 2017. 'Structured literature review about intellectual capital and innovation'. Journal of Intellectual Capital, 18(2), 262-285. DOI: https://doi. org/10.1108/JIC-07-2016-0069.

Cassetta, E., Meleo, L. and Pini, M. 2016. 'The role of digitalization in the internationalization of Italian manufacturing firms'. L'industria, 37(2), 305-328.

Cirillo, V. 2016. 'Technology, employment and skills'. Economics of Innovation and New Technology, 26(8), 734-754. DOI: https://doi.org/10.1430/84077.

Comuzzi, M. and Patel, A. 2016. 'How organizations leverage big data: a maturity model'. Industrial Management \& Data Systems, 116(8), 1468-1492. DOI: https://doi. org/10.1108/IMDS-12-2015-0495.

Cowen, T. 2013. Average is over: Powering America beyond the Age of the Great Stagnation. Penguin, New York.

Díaz-Chao, Á., Sainz-González, J. and Torrent-Sellens, J. 2015. 'ICT, innovation, and firm productivity: new evidence from small local firms'. Journal of Business Research, 68(7), 1439-1444. DOI: https://doi.org/10.1016/j.jbusres.2015.01.030.

Dost, M., Badir, Y.F., Ali, Z. and Tariq, A. 2016. 'The impact of intellectual capital on innovation generation and adoption'. Journal of Intellectual Capital, 17(4), 675-695. DOI: https://doi.org/10.1108/JIC-04-2016-0047.

EU Parliament. 2015a. 'Industry 4.0. Digitalisation for productivity and growth', available at: http://www.europarl.europa.eu/RegData/etudes/BRIE/2015/568337/ EPRS_BRI(2015)568337_EN.pdf. 
EU Parliament. 2015b. 'Industry 4.0', available at: http://www.europarl.europa.eu/ RegData/etudes/STUD/2016/570007/IPOL_STU(2016)570007_EN.pdf.

Evangelista, R., Guerrieri, P. and Meliciani, V. 2014. 'The economic impact of digital technologies in Europe'. Economics of Innovation and New Technology, 23(8), 802-824. DOI: https://doi.org/10.1080/10438599.2014.918438.

Faria, A., Fenn, P. and Bruce, A. 2002. 'Determinants of adoption of flexible production technologies: evidence from Portuguese manufacturing industry'. Economics of Innovation and New Technology, 11(6), 569-580. doi: 10.1080/10438590214338.

Federmeccanica 2016. 'Industria 4.0 in Italia: l'indagine di Federmeccanica', Rome, available at: https://www.federmeccanica.it/archivio-eventi/dettaglievento/29/ industria-4-0-in-italia-l-indagine-di-federmeccanica.html.

Fichman, R. 2012. 'Lecture note: digital innovation value maximization'. Boston College, available at: https://www2.bc.edu/ fichman/LN-Innovation-Value.Pdf.

Fink, L. 2007. 'Coordination, learning, and innovation: the organizational roles of ecollaboration and their impacts'. International Journal of E-collaboration, 3(3), 53-70.

Fondazione Nord-Est. 2015. Make in Italy. Il primo rapporto sull'impatto delle tecnologie digitali nel sistema manifatturiero italiano. Fondazione Make in Italy CDB.

Fosso Wamba, S., Akter, S., Edwards, A., Chopin, G. and Gnanzou, D. 2015. 'How "big data" can make big impact: findings from a systematic review and a longitudinal case study'. International Journal of Production Economics, 165, 234-246, DOI: https://doi. org/10.1016/j.ijpe.2014.12.031.

Frey, C.B. and Osborne, A.O. 2017. 'The future of employment: how susceptible are jobs to computerisation?' Technological Forecasting \& Social Change, 114, 254-280, DOI: https://doi.org/10.1016/j.techfore.2016.08.019.

Gordon, R.J. 2016. The Rise and Fall of American Growth: The US Standard of Living since the Civil War. Princeton University Press, Princeton.

Grover, V. and Kohli, R. 2012. 'Cocreating IT value: new capabilities and metrics for multifirm environments'. MIS Quarterly, 36(1), 225-232.

Guarascio, D. and Pianta, M. 2016. 'The gains from technology: new products, exports and profits'. Economics of Innovation and New Technology, 26(8), 779-804. DOI: https:// doi.org/10.1080/10438599.2016.1257446.

Hartmann, P.M., Zaki, M., Feldmann, N. and Neely, A. 2016. 'Capturing value from big data: a taxonomy of data-driven business models used by start-up firms'. International Journal of Operations \& Production Management, 36(10), 1382-1406. doi: 10.1108/ IJOPM-02-2014-0098.

Henfridsson, O., Mathiassen, L. and Svahn, F. 2014. 'Managing technological change in the digital age: the role of architectural frames'. Journal of Information Technology, 29(1), 27-43. DOI: https://doi.org/10.1057/jit.2013.30.

Heng, S. 2014. 'Industry 4.0: upgrading of Germany's industrial capabilities on the Horizon', available at: https://ssrn.com/abstract $=2656608$.

Hermann, M., Pentek, T. and Otto, B. 2015. 'Design principles for Industrie 4.0 scenarios'. DOI: https://doi.org/10.1109/HICSS.2016.488.

Higón, D.A. and Driffield, N. 2011. 'Exporting and innovation performance: analysis of the Annual Small Business Survey in the UK'. International Small Business Journal, 29(1), 4-24. DOI: https://doi.org/10.1177/0266242610369742.

Hinds, P.J. and Kiesler, S. 2002. Distributed Work: New Research on Working across Distance Using Technology. MIT Press, Cambridge, MA. 
Hofmann, E. and Rüsch, M. 2017. 'Industry 4.0 and the current status as well as future prospects on logistics'. Computers in Industry, 89, 23-34. DOI: https://doi. org/10.1016/j.compind.2017.04.002.

Hsiao, C. 1996. 'Logit and probit models'. In The Econometrics of Panel Data, pp. 410-428. Springer, Dordrecht.

Kagermann,H.,Helbig,J.,Hellinger,A. andWahlster,W.2013.'Umsetzungsempfehlungen für das Zukunftsprojekt Industrie 4.0: Deutschlands Zukunft als Produktionsstandort sichern; Abschlussbericht des Arbeitskreises Industrie 4.0. Forschungsunion'. Abschlussbericht des Arbeitskreises Industrie.

Kang, H.S., Lee, J.Y., Choi, S., Kim, H., Park, J.H., Son, J.Y., Kim, B.H. and Noh, S.D. 2016. 'Smart manufacturing: past research, present findings, and future directions', International Journal of Precision Engineering and Manufacturing-Green Technology, 3(1), 111-128. DOI: https://doi.org/10.1007/s40684-016-0015-5.

Katz, J.E. and Rice, R.E. 2002. Social Consequences of Internet Use: Access, Involvement, and Interaction. MIT Press, Cambridge, MA.

LaValle, S., Lesser E., Shockley, R., Hopkins, M.S. and Kruschwitz, N. 2011. 'Big data, analytics and the path from insights to value'. MIT Sloan Management Review, 52(2), 20-33.

Liao, Y., Deschamps, F., Loures, E.D.F.R. and Ramos, L.F.P. 2017. 'Past, present and future of Industry 4.0: a systematic literature review and research agenda proposal'. International Journal of Production Research, 55(12), 3609-3629. DOI: https://doi. org/10.1080/00207543.2017.1308576.

Lu,Y.2017. 'Industry 4.0: a survey on technologies, applications and open research issues'. Journal of Industrial Information Integration, 6, 1-10. DOI: https://doi.org/10.1016/ j.jii.2017.04.005.

Lycett, M. 2013. "Datafication”: making sense of (big) data in a complex world'. European Journal of Information Systems, 22(4), 381-386. doi: 10.1057/ejis.2013.10.

McGuirk, H., Lenihan, H. and Hart, M. 2015. 'Measuring the impact of innovative human capital on small firms' propensity to innovate'. Research Policy, 44(4), 965-976. DOI: https://doi.org/10.1016/j.respol.2014.11.008.

McQuivey, J. 2013. Digital Disruption. Forrester Research, Amazon Publishing, Las Vegas.

Morgan-Thomas, A. and Jones, M.V. 2009. 'Post-entry internationalization dynamics'. International Small Business Journal, 27(1), 71-97. DOI: https://doi.org/10.1177/ 0266242608098347.

OECD. 2014. Measuring the Digital Economy: A New Perspective. OECD Publishing, Paris.

OECD. 2015. Data-Driven Innovation: Big Data for Growth and Well-Being. OECD Publishing, Paris.

Pearson, K. 1900. 'On the criterion that a given system of deviations from the probable in the case of a correlated system of variables is such that it can be reasonably supposed to have arisen from random sampling'. Philosophical Magazine Series 5, 50(302), 157-175.

Pisano, G.P. andVerganti, R. 2008. 'Which kind of collaboration is right for you?' Harvard Business Review, 86(2), 78-86.

Plackett, R. 1983. 'Karl Pearson and the chi-squared test'. International Statistical Review/ Revue Internationale de Statistique, 51(1), 59-72.DOI: https://doi.org/10.2307/1402731. 


\section{Giancarlo Corò and Mario Volpe}

Platform I4.0. 2015. 'Von smarten Objekten und Maschinen', available at: http://www. plattform-i40.de.

Rullani,E. 1989.'La teoria dell'impresa: soggetti, sistemi, evoluzione'. In Rispoli M.(ed.), L'impresa industriale. Economia, tecnologia, management. Il Mulino, Bologna, pp. 13-110.

Rüßmann, M., Lorenz, M., Gerbert, P., Waldner, M., Justus, J., Engel, P. and Harnisch, M. 2015. 'Industry 4.0: the future of productivity and growth in manufacturing industries'. Boston Consulting Group.

Schmidt, R., Möhring, M., Härting, R.C., Reichstein, C., Neumaier, P. and Jozinovic, P. 2015. 'Industry 4.0: potentials for creating smart products: empirical research results'. Business Information Systems, 16-27. DOI: https://doi.org/10.1007/978-3319-19027-3_2.

Schröder, C. 2016. 'The challenges of Industry 4.0 for small and medium-sized enterprises'. Friedrich-Ebert-Stiftun, Division of Economic and Social Policy, Bonn.

Schwab, K. 2016. The Fourth Industrial Revolution. World Economic Forum, Geneva.

Secundo, G., DelVecchio, P., Dumay, J. and Passiante, G. 2017. 'Intellectual capital in the age of big data: establishing a research agenda'. Journal of Intellectual Capital, 18(2), 242-261. DOI: https://doi.org/10.1108/JIC-10-2016-0097.

Shafiq, S.I., Sanin, C., Szczerbicki, E. and Toro, C. 2016. 'Virtual engineering factory: creating experience base for Industry 4.0'. Cybernetics and Systems, 47(1-2), 32-47. DOI: https://doi.org/10.1080/01969722.2016.1128762.

Shafiq, S.I., Sanin, C., Toro, C. and Szczerbicki, E. 2015. 'Virtual engineering object (VEO): toward experience-based design and manufacturing for Industry 4.0'. Cybernetics and Systems, 46(1-2), 35-50. DOI: https://doi.org/10.1080/01969722.2015. 1007734.

Sommer, L. 2015. 'Industrial revolution - Industry 4.0: are German manufacturing SMEs the first victims of this revolution?' Journal of Industrial Engineering and Management, 8(5), 1512-1532. DOI: https://doi.org/10.3926/jiem.1470.

Thames, L. and Schaefer, D. 2016. 'Software-defined cloud manufacturing for Industry 4.0'. Procedia CIRP, 52, 12-17. DOI: https://doi.org/10.1016/j.procir.2016.07.041.

Vaccaro, A. and Madsen, P. 2009. 'ICT and an NGO: difficulties in attempting to be extremely transparent'. Ethics and Information Technology, 11(3), 221-231. doi: 10.1007/ s10676-009-9180-3.

Yoo, Y., Boland, R.J., Jr., Lyytinen, K. and Majchrzak, A. 2012. 'Organizing for innovation in the digitized world’. Organization Science, 23(5), 1398-1408. DOI: https:// doi.org/10.1287/orsc.1120.0771. 